\title{
Micromorphology in Mycale taxonomy (Mycalidae, Poecilosclerida, Demospongiae), with the description of two new micracanthoxea-bearing species
}

José Luis Carballo ${ }^{1}$ \& Eduardo Hajdu ${ }^{2}$

${ }^{I}$ Facultad de Ciencias del Mar; Universidad de Sinaloa, Paseo Claussen $s / n$, Apartado Postal 610, C.P. 8200, Mazatlán, Sin., México. E-mail: carballo@ola.icmyl.unam.mx. ${ }^{2}$ Departamento de Zoologia, Instituto de Biociências, Universidade de São Paulo, Cx. Postal 11461, São Paulo, SP, 05422-970, Brazil. E-mail: hajdu@usp.br, and Departamento de Invertebrados, Museu Nacional, Universidade Federal do Rio de Janeiro, Quinta da Boa Vista, s/n, Rio de Janeiro 20940-040, Brazil

Keywords: Poecilosclerida, Mycalidae, Mycale, taxonomy, micromorphology, phylogeny, microscleres, scanning electron microscopy

\begin{abstract}
Two new species of Mycale with micracanthoxeas are described: Mycale (Aegogropila) lilianae $\mathrm{n}$. sp., mainly characterized by the presence of toxas as large as $300 \mu \mathrm{m}$, and Mycale (Carmia) urizae n. sp., the first Mycale with micracanthoxeas described from Africa, characterized by the presence of anisochelae-III with the falx projecting downwards from the middle basal portion of the frontal alae of the head, and by the presence of two morphologically distinct size classes of toxas, with toxas-II being notably oxea-shaped. A discussion of all species of Mycale with micracanthoxeas is included. It is postulated that a comprehensive assessment of the distribution of this character, as well as of other micromorphological features of Mycale spicules, may shed light on the affinities and redefinition of obscure subgenera such as Aegogropila and Carmia.
\end{abstract}

\section{Resumen}

En este trabajo se describen dos especies nuevas de Mycale con microacanthoxeas: Mycale (Aegogropila) lilianae $\mathrm{n}_{\mathrm{.}} \mathrm{sp}$, , caracterizada principalmente por la presencia de toxas de hasta $\mathbf{3 0 0}$ $\mu \mathrm{m}$ de longitud, y Mycale (Carmia) urizae n. sp., caracterizada por la presencia de una proyección en el centro de las alas superiores de las anisoquelas III, $y$, por tener toxas distinguỉbles en tamaño y forma, destacando la forma en oxa de la categoria II. Esta especie, es además, la primera Mycale con micracanthoxeas descrita para las costas de Africa. También se realiza una discusión taxonómica de todas las especies de. Mycale con micracanthoxeas, y se postula sobre la importancia filogenética de este carácter, así como de otros caracteres micromorfológicos, en los diferentes subgeneros de Mycale como Aegogropila y Carmia.

\section{Introduction}

Mycale is a sponge genus of poecilosclerid with a high degree of diversity (number of categories) and disparity (variability within a single category, and among several categories) of microscleres. Categories may be recognized due to their conspicuously distinct shape, or merely by gaps in their size-range. Currently, more than 150 species of Mycale have been described in the world (e.g., Doumenc \& Lévi, 1987), but the generally complex set of morphological characters of these species (up to eight categories of microscleres) tends to make their identification fairly straightforward (Hajdu \& Desqueyroux-Faundez, 1994).

The presence of micracanthoxeas as a spicular element in the genus Mycale was first mentioned for $M$. micracanthoxea Buizer \& Van Soest, 1977, originally reported from the northeastern Atlantic Ocean, and later from the Strait of Gibraltar (Carballo \& García-Gómez, 1994). There are three species of Mycale known with this microsclere type: the already mentioned $M$. micracanthoxea, M. bamfieldense from the Pacific Ocean (Reiswig \& Kaiser, 1989) and M. escarlatei from the tropical western Atlantic (Hajdu et al, 1995). We describe here two more species with this microsclere category. Mycale lilianae $\mathrm{n}$. sp. is the second species with micracanthoxeas found on the southeastern coast of Brazil, and Mycale urizae 
n. sp. is the first species with micracanthoxeas described from the African coast.

All the Mycale species with micracanthoxeas that are currently known belong to two subgenera based on the presence (Aegogropila) or the absence (Carmia) of a tangential ectosomal skeleton. Strong arguments against the monophyly of these groupings were put forward elsewhere (Hajdu \& Desqueyroux-Faúndez, 1994; Hajdu \& Rützler, unpubl. res.), and are touched upon here again. Species assigned to Aegogropila are: $M_{\text {. }}($ A.) bamfieldense Reiswig \& Kaiser, 1989, M. (A.) escarlatei Hajdu, Zea, Kielman \& Peixinho, 1995, and M. (A.) lilianae n. sp.; and to Carmia: M. (C.) micracanthoxea Buizer \& Van Soest, 1977 and M. (C.) urizae $\mathrm{n}$. sp.

\section{Material and methods}

Specimens were collected by scuba diving and preserved in $96 \%$ ethanol. The preparation of dissociated spicules, both for light, and scanning electron microscopy (SEM) followed the techniques described in Rützler (1978) and Hajdu (1994). The Namibian material was studied on a Philips XL 20 SEM of the Servicio de Microscopia Electrónica of the Universidad de Sevilla, under accelerating voltages between 25 and $30 \mathrm{Kv}$ and magnifications up to $9013 \times$. The Brazilian material was partly studied on a Jeol JSM 35-L SEM, of the Institute for Systematics and Population Biology (University of Amsterdam), under an accelerating voltage of $25 \mathrm{Kv}$ and magnifications up to $2400 \times$; and partly on a Zeiss DSM940 SEM, of the Laboratório de Mícroscopia Eletrônica (Departamento de Zoologia, Instituto de Biociências, Universìdade de São Paulo [DZUSP]), under accelerating voltages of 17 to $19 \mathrm{Kv}$ and magnifications up to $10000 x$.

\section{Systematic deseriptions}

Order Poecilosclerida Topsent, 1928

Suborder Mycalina Hajdu, Van Soest \& Hooper, 1994

Family Mycalidae Lundbeck, 1905

Genus Mycale Gray, 1867

Subgenus Aegogropila Gray, 1867

Diagnosis. - Mycale with an, often regular, tangential, ectosomal reticulation of spicule bundles that often easily peel off, and no serrated sigmas.
Anisochelae palmate. Type species: Aegogropila varians Gray, 1867 (cf. Hajdu et al., 1995).

\section{Mycale (Aegogropila) lilianae n. sp. (Fig. 1)}

Material studied. - Holotype - DZUSP 381, Petrobras' Tankers' Pier (moles 96 to $101 ; 2^{\circ} 48.18^{\prime} \mathrm{S}-45^{\circ} 23.20^{\prime} \mathrm{W}$ ), São Sebastião, SP, Brazil, 12-14 m depth, coll. E. Hajdu, 30/01/ 1996. Paratypes - DZUSP 296 and 302, Farolete (small lighthouse; $23^{\circ} 49.67^{\prime} \mathrm{S}=45^{\circ} 24.75^{\prime} \mathrm{W}$ ), Praia Grande, São Sebastião, SP, Brazil, 1-15 m depth, colls. E. Hajdu and G. Muricy, 24/01/1996; DZUSP 369, Farolete, Praìa Grande, São Sebastião, SP, Brazil, 1-8 m depth, coll. E. Hajdu, 29/01/1996. Schyzotypes (from holotype) - The Natural History Museum, London, cat. no. BMNH-1997.2.26.1; Zoological Museum Amsterdam, cat. no. ZMA Por. 11513.

Diagnosis. - Mycale (Aegogropila) with micracanthoxeas, with anisochelae-I, -II, -III, sigmas-I and -II, toxas larger than $200 \mu \mathrm{m}$.

Description. - Specimens are thinly to thickly encrusting but are mostly less than $1 \mathrm{~mm}$ thick. Substrate is varied and includes many bivalves and anthozoans (Carijoa sp.) (Fig. 1h). Covered area ranges from 1 (DZUSP 296) to over $10 \mathrm{~cm}^{2}$ (holotype). The consistency is soft and fragile and the surface is not easily peeled off. Subectosomal canals are distinctly visible in thicker preserved specimens (holotype), and convergence to oscula in a starry pattern is present. There is, nevertheless, only a single visible contracted osculum. Live colours range from light yellow (DZUSP 296), yellow (DZUSP 369), through orange (DZUSP 302), to reddish-orange (holotype). The latter may have been influenced by the colour of the underlying anthozoan.

Skeletal structure: the ectosomal skeleton is made of a tangental reticulation of tracts of mycalostyles, ca. $40 \mu \mathrm{m}$ wide, which is slightly pierced here and there by projecting mycalostyles of the choanosomal tracts $(30-90 \mu \mathrm{m}$ beyond the surface), of the same single category. Meshes formed by the reticulation are $50-350 \mu \mathrm{m}$ wide. Sievelike pore fields are visible inside some of the meshes. Ostia are 20-70 $\mu \mathrm{m}$ wide in dry material (prepared for SEM). Criss-crossing mycalostyles are common tangentially to the surface, as well as anisochelae-I, -II, and -III, sigmas-I, and toxas. Anisochelae-I are mostly organized in rosettes, up to $110 \mu \mathrm{m}$ wide, with 2-11 spicules, which 


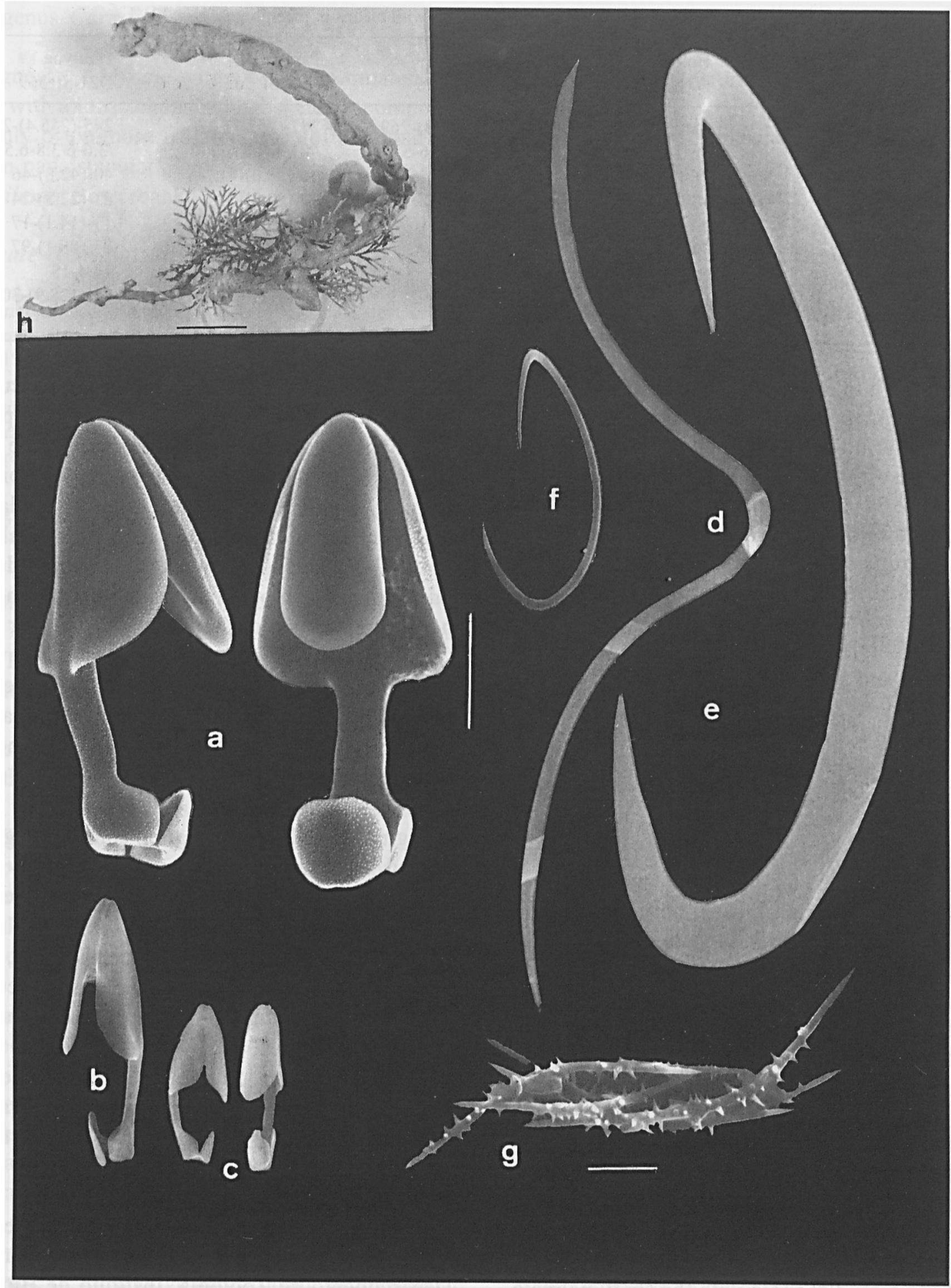

Fig. 1. SEM micrographs of the spicules and holotype of Mycale lilianae n. sp.: a, anisochelae-I, side and face views; $b$, anisochela-II, side view; c, anisochelae-III, side and face views; d, toxa; e, sìgma-I; f, sigma-II; g, micracanthoxeas; $h$, holotype. (Scale bar: a, b, c, $\mathrm{d}, \mathrm{e}, \mathrm{f}=10 \mu \mathrm{m} ; \mathrm{g}=2 \mu \mathrm{m} ; \mathrm{h}=1 \mathrm{~cm}$.) 
Table I. Spicule sizes for Mycale lilianae $\mathrm{n}$. sp. Measurements are in $\mu \mathrm{m}$, with means in parentheses. $\mathrm{N}=\mathbf{2 0}$.

\begin{tabular}{lllll}
\hline & $\begin{array}{l}\text { Holotype } \\
\text { DZUSP381 }\end{array}$ & $\begin{array}{l}\text { Paratype } \\
\text { DZUSP 296 }\end{array}$ & $\begin{array}{l}\text { Paratype } \\
\text { DZUSP 302 }\end{array}$ & $\begin{array}{l}\text { Paratype } \\
\text { DZUSP 369 }\end{array}$ \\
\hline Mycalostyles (length/ & $238-(260.3)-283$ & $245-(254.3)-269$ & $242-(252.7)-276$ & $245-(255.4)-266$ \\
head-width/shaft-width) & $14.1-4.8 / 4.6-6.2$ & $14.1-5.3 / 4.6-5.5$ & $14.1-6 / 4.8-6.2$ & /3.6-6/3.8-6.5 \\
Anisochelae-I & $36-(38.2)-43$ & $36-(41.4)-46$ & $36-(38.6)-41$ & $40-(42.8)-46$ \\
Anisochelae-II & $19-(20.7)-23$ & $20-(22.0)-23$ & $19-(20.8)-24$ & $21-(22.3)-24$ \\
Anisochelae-III & $12-(13.8)-14$ & $12-(14.4)-16$ & $13-(13.6)-14$ & $11-(14.1)-17$ \\
Sigmas-I & $77-(81.7)-88$ & $80-(88.7)-96$ & $77-(82.0)-89$ & $83-(88.1)-97$ \\
Sigmas-II & ca. 24 & $17.1-26.4$ & not found & $14.4-18$ \\
Toxas & $62-(116.9)-233$ & $58-(116.7)-283$ & $60-(109.0)-317$ & $70-(128.9)-307$ \\
Micracanthoxeas & $9-11$ & $6.0-7.3$ & ca. 6.4 & $9-13$ \\
\hline
\end{tabular}

vary from rare to common. Some rosettes, as well as many sigmas-I, appear to be placed around tracts of mycalostyles. The choanosomal skeleton is made of wavy, ascending tracts of mycalostyles, mostly 20-35 $\mu \mathrm{m}$ thick. Tracts branch towards the ectosome where they diverge in paucispicular tufts which support and slightly pierce the ectosomal reticulum and surface peel.

Spicules (dimensions of. Table I). Megascleres: Mycalostyles are slender, very homogeneously sized and shaped. They range from straight to sub-sinuous or slightly curved. Marginally fusiform, gradually tapering to both neck and sharp apex. Heads elliptic, compressed longitudinally. Axial canal clearly visible, only slightly inflated in the head.

Microscleres: Anisochelae-I. Shaft (sub)straight on profile view, moderately stout, palmate head (55-60\% of total length), basal portion of lateral alae projecting only slightly backwards, frontal alae typically forming a ca. $45^{\circ}$ angle with the shaft; palmate foot (17-21 \% of total length), frontal alae seldom taller than lateral ones, occasionally a rounded bump (projecting falx) is present on the central portion of its upper surface; on face view, shaft straight, or more often, thicker near the foot (Fig. 1a)...

Anisochelae-II. Shaft slightly curved on profile view, slender, palmate head (ca. $60 \%$ of total length), basal portion of lateral alae projecting only slightly backwards, frontal alae typically forming a ca. $30^{\circ}$ angle with the shaft; palmate foot (17-21 \% of total length), alae often reduced, falx commonly projecting as a digit from the upper central portion of the frontal ala; slender shaft (Fig. 1b).
Anisochelae-III. Slender, shaft slightly curved on profile view, with a marked curve in opposite direction near the upper part of the palmate head (ca. $60 \%$ of total length), frontal alae typically forming a ca. $30^{\circ}$ angle with the shaft, lateral alae commonly fused with frontal one; palmate foot (20-30\% of total length), alae often reduced, falx commonly projecting as a digit from the upper central portion of the frontal ala; slender shaft (Fig. 1c).

Sigmas-I. Stout, contorted, gently curved on most of its extension, abruptly bent terminations leading to very sharp endings (Fig. 1e). Endings often blade-like (abruptly sharpened as in many Hamacantha).

Sigmas-II. Slender, fragile, contorted, gently curved on most of its extension, abruptly bent terminations leading to very sharp, spine-like endings (Fig. 1f).

Toxas. Variably sized and shaped, smooth, slender, central curve often marked, lateral curves often gentle, gradually tapering to sharp endings (Fig. 1d).

Micracanthoxeas. Variably bent on middle portion, heavily spined, spines absent from terminations, and probably as large as the shaft's thickness (Fig. 1g).

Etymology. - The present species is named $l i-$ lianae after Prof. Dr. Liliana Forneris, from the Departamento de Zoologia, Instituto de Biociências, of Universidade de São Paulo, who markedly contributed to EH's interest in the field of science, and for her decades of commitment to marine biology in Brazil. 
Subgenus Carmia Gray, 1867

Diagnosis. - Mycale without an ectosomal skeleton, with a loose choanosomal skeleton composed mainly of plumose isolated spiculofibers that are often paucispicular. Type species: Hymeniacidon macilenta Bowerbank, 1866.

\section{Mycale (Carmia) urizae n. sp. (Fig. 2)}

Material studied: Holotype in Museo Nacional de Ciencias Naturales (Madrid) 1.01/174, Possesion Island $27^{\circ} 00^{\prime} 45 \mathrm{~S}$ $15^{\circ} 11^{\prime 76} \mathrm{~W}$ (Namibia), 5-8 m depth, coll. J.L. Carballo, 05/12/ 95. Among roots of Laminaria sp., over rocks, etc. Schyzotypes (spicules from holotype) have been deposited in the Laboratorio de Biologia Marina of the Universidad de Sevilla with ref, no. LBM-05/12/95-1/040.

Diagnosis. - Mycale (Carmia) with micracanthoxeas, with anisochelae-I, -II, -III. Anisochelae-III with the falx projecting downwards from the middle basal portion of the frontal ala of the head, with two morphologically distinct size classes of toxas. Toxas-II are characteristically oxea-shaped. Slightly slimy.

Description. - Cushion-shaped specimen about 1 $\mathrm{cm}$ thick. Maximum substratum coverage several $\mathrm{cm}^{2}$, with $12 \mathrm{~cm}$ at its greatest horizontal diameter. The body of the sponge holds tubes of sabellid polychaetes, bryozoans, etc. The consistency is firm but compressible. The surface is very irregular and characteristic, with uneven swellings and occasional protuberances when seen from the top. We have not observed oscules or subectosomal canals. The ectosome is translucent, not supported by any specialized skeleton. Colour in life is light brown. The species is slightly slimy out of the water.

Skeletal structure: there is no tangential ectosomal skeleton, only some loose spicules. Anisochelae in rosettes have not been observed either. The choanosomal skeleton has a plumo-reticulated architecture; tracts of mycalostyles arise from the base of the sponge and protrude at the sponge surface. In the flesh between the tracts, the microscleres are strewn at random without any special arragement. Spongin is scarce.

Spicules: Megascleres: Mycalostyles usually straight or slightly bent, often with hardly perceptible tyle, and very homogeneous in length (Fig. 2g). Dimensions: 200-(243.5)-272.5 x 7-9 $\mu \mathrm{m}$.

Microscleres: Anisochelae-I (Fig. 2a). Dimensions: 44.5-(49.6)-58.5 $\mu \mathrm{m}$, palmate head (51-54 $\%$ of total length), palmate foot (20-22 \% of total length).

Anisochelae-II (Fig. 2b). Dimensions: 24-(26.8)$31 \mu \mathrm{m}$, palmate head (66-69 \% of total length), palmate foot (15-18\% of total length).

Anisochelae-III, characteristically with the falx projecting downwards from the middle basal portion of the frontal ala of the head, and with a similar opposite projection from the foot. Shaft slightly curved on profile view (Fig. 2c). Dimensions: 9.5-(12.3)-15 $\mu \mathrm{m}$, palmate head (57-61 \% of total length), palmate foot (28-30\% of total length).

Sigmas, robust, contorted (Fig. 2e), rare. Dimensions: 70-(89.5)-105.5 $\mu \mathrm{m}$.

Toxas-I, bow-shaped (Fig. 2d). Dimensions: 75(104.8)-120.5 x 2-3 $\mu \mathrm{m}$.

Toxas-II, thin, oxea-shaped (Fig. 2d), very homogeneous in length and very abundant. Dimensions: 22-(28.2)-30.5 $\mu \mathrm{m}$.

Micracanthoxeas, slender, slightly curved, with many small perpendicular spines (Fig. 2e). Dimensions: 6-(8.9)-15.5 $\mu \mathrm{m}$.

Etymology. - The species is named after Dr. $\mathbf{M}^{\mathrm{a}}$ Jesús Uriz of the Centro de Estudios Avanzados de Blanes (C.S.I.C., Girona, Spain) for her dedication to the study of the sponge fauna of the Iberian Peninsula, for her friendship and constant encouragement with the sometimes frustrating research on sponges.

Remarks. - Other species bearing micracanthoxeas known to date, apart from those described above, are Mycale (Carmia) micracanthoxea, $M$. (Aegogropila) bamfieldense, and M. (A.) escarlatei. M. micracanthoxea differs from $M$. (A.) lilianae $\mathrm{n} . \mathrm{sp}$. in the absence of a specialized ectosomal skeleton, of a third category of anisochelae, in the presence of stouter sigmas-I, and of toxas less variable in size (13-120 vs. $58-317 \mu \mathrm{m})$. It differs from $M$. urizae $\mathrm{n}$. sp in the smaller size of 


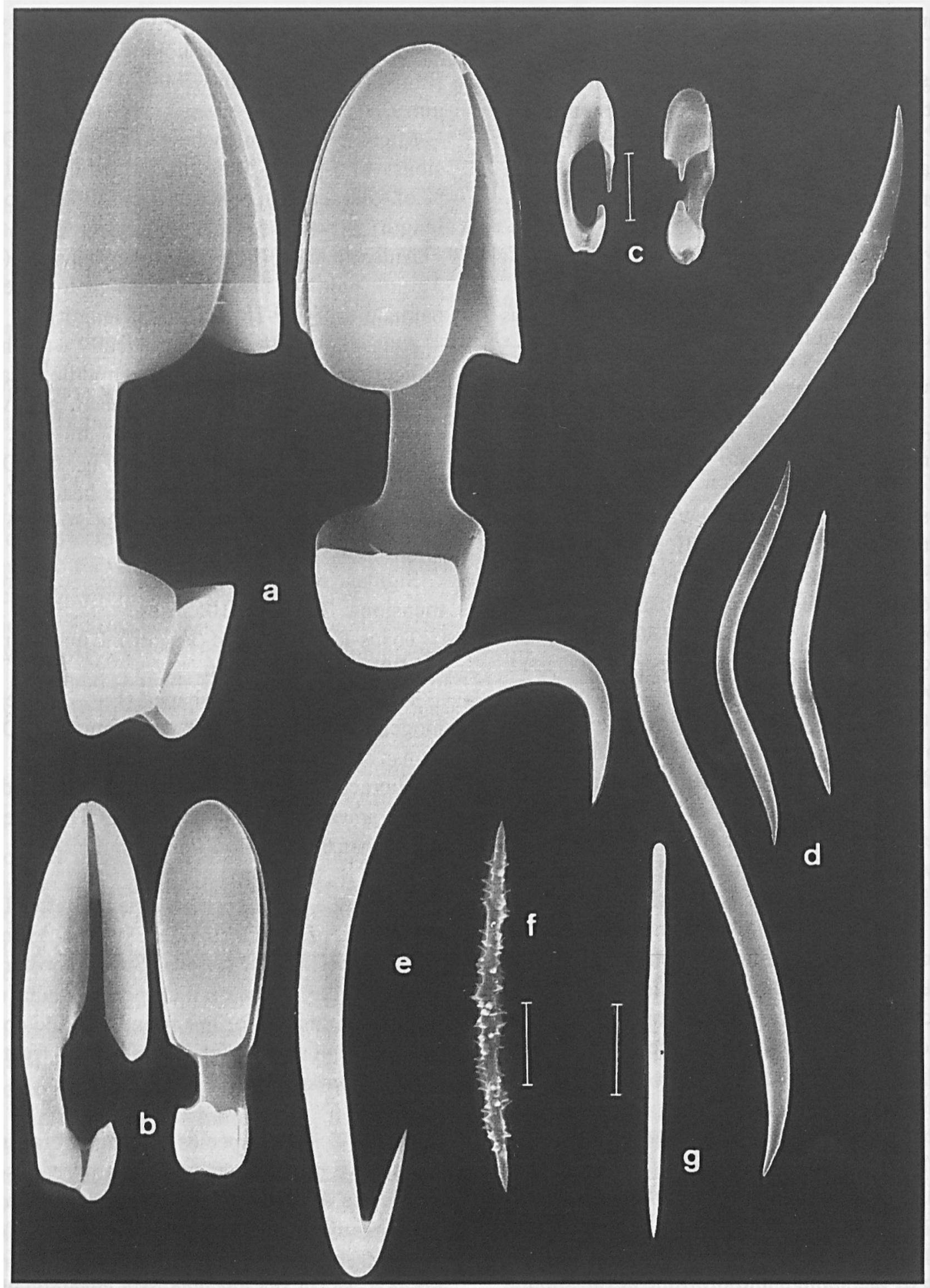

Fig. 2. SEM micrographs of spicules of Mycale urizae n. sp.: a, anisochelae-I, side and face views; b, anisochelae-II, side and face views; $c$, anisochelae-III, side and face views; d, toxa-I (larger) and toxas-II (smaller); e, sigma; $f$ micracanthoxea; $g$, mycalostyle. (Scale bar: $\mathrm{a}, \mathrm{b}, \mathrm{c}, \mathrm{d}=5 \mu \mathrm{m} ; \mathrm{e}=10 \mu \mathrm{m}, \mathrm{f}=2 \mu \mathrm{m}, \mathrm{g}=50 \mu \mathrm{m}$.) 
Table II. Spicule sizes (in $\mu \mathrm{m}$ ) and other comparative features of Mycale species with micracanthoxeas.

\begin{tabular}{|c|c|c|c|c|c|c|}
\hline & $\begin{array}{l}\text { M. micracanthoxea } \\
\text { Buizer \& } \\
\text { Van Soest, } 1977\end{array}$ & $\begin{array}{l}\text { M. micracanthoxea } \\
\text { ef. Carballo \& } \\
\text { Garcia-Gómez, } 1994\end{array}$ & $\begin{array}{l}\text { M. bamfieldense } \\
\text { Reiswig \& } \\
\text { Kaiser, } 1989\end{array}$ & $\begin{array}{l}\text { M. escarlatei } \\
\text { Hajdu et al. } \\
1995\end{array}$ & M. Ilianae n. sp. & M. urizae n. sp. \\
\hline $\begin{array}{l}\text { Mycalostyles } \\
\text { Anisochelae-I } \\
\text { Anisochelae-II } \\
\text { Anisochelae-III } \\
\text { Sigmas-I } \\
\text { Sigmas-II } \\
\text { Toxas-I } \\
\text { Toxas-II } \\
\text { Micracanthoxeas } \\
\text { Tangential ectosomic } \\
\text { skeleton } \\
\text { Slime } \\
\text { Distribution }\end{array}$ & $\begin{array}{l}256-285 \times 7-7.5 \\
20-32 \\
13-20 \\
58-89 \\
19-24 \\
100-120 \\
13-20 \\
7-8.5 \\
\text { absent } \\
\text { not reported } \\
\text { NE Atlantic Ocean } \\
\text { (Holland), intertidal, } \\
\text { sublittoral zone, } \\
\text { harbour poles }\end{array}$ & $\begin{array}{l}216-256 \times 3.8-6.5 \\
= \\
11-15 \\
38-50 \\
16-30 \\
90-130 \\
3-6 \\
\text { absent } \\
\text { absent } \\
\text { NE Atlantic Ocean } \\
\text { (Spain), sublittoral } \\
\text { zone, harbour poles }\end{array}$ & $\begin{array}{l}247-297 \times 2.8-11.7 \\
28-41 \\
16-24 \\
9.4-16.9 \\
33-75 \\
13-24 \times \\
19-70 \\
= \\
3.2-7.1 \\
\text { present } \\
\text { not reported } \\
\text { N Pacific Ocean } \\
\text { (Canada), intertidal } \\
\text { cave }\end{array}$ & $\begin{array}{l}254-350 \times 8-11 \\
34-46 \\
24-32 \\
13-14 \\
63-77 \\
20-31 \\
74-77 \\
9-22 \\
3.4 \\
\text { present } \\
\text { absent } \\
\text { SW Atlantic } \\
\text { Ocean (Brazil), } \\
\text { from subtidal to } \\
\text { sublittoral zone }\end{array}$ & $\begin{array}{l}245-269 \times 4.6-5.5 \\
36-46 \\
20-23 \\
12-16 \\
80-96 \\
17.1-26.4 \\
58-283 \\
= \\
6-7.3 \\
\text { present } \\
\text { absent } \\
\text { SW Atlantic } \\
\text { Ocean (Brazil), } \\
\text { sublittoral zone }\end{array}$ & $\begin{array}{l}200-273 \times 7.9 \\
44.5-59 \\
24-31 \\
9.5-15 \\
70-106 \\
= \\
75-121 \\
22-31 \\
6-15.5 \\
\text { absent } \\
\text { present } \\
\text { SE Atlantic } \\
\text { Ocean } \\
\text { (Namibia), } \\
\text { sublittoral zone }\end{array}$ \\
\hline
\end{tabular}

the sigmas-I (38-89 vs. $70-106 \mu \mathrm{m})$, presence of sigmas-II, and smaller micracanthoxeas (3-8.5 vs. 6-17.3 $\mu \mathrm{m}$ ). Mycale (A.) bamfieldense appears to be the closest to $M$. (A.) lilianae n. sp., from which it differs nevertheless, by the possession of stouter megascleres (up to $12 \mu \mathrm{m}$ vs. less than $6.5 \mu \mathrm{m})$, and much smaller toxas (19-70 vs. $58-$ $317 \mu \mathrm{m})$ and micracanthoxeas (3-7 vs. 6-13.3 $\mu \mathrm{m})$. Mycale (A.) bamfieldense has a much gentler toxa angle than in most toxas of $M$. lilianae n. sp., where especially the smaller toxas tend to be more sharply curved in their middle portion. Mycale (A.) bamfieldense differs from $M$. urizae $\mathrm{n} . \mathrm{sp}$ in the possession of an ectosomal tangential reticulation of megasclere bundles, possession of smaller sigmas-I (35-75 $\mu \mathrm{m}$ vs. $70-106 \mu \mathrm{m})$, and possession of sigmas-II (Table II). Mycale escarlatel is set apart from both new species by its peculiarlyshaped anisochelae-II (like a duck's-bill, sensu Thomas (1968), centrotylote toxas-II, as well as bright-red colour. It differs further from $M \times$ uri$z a e \mathrm{n}$. sp. by the possession of a specialized ectosomal reticulation. Finally, M. (A.) lilianae differs from $M$. (C.) urizae by the presence of an ectosomal reticulation, sigmas-II, and more sizevariable toxas (58-317 vs. $22-120 \mu \mathrm{m})$. Both species differ in regard to the shape of their anisochelae-I and -III, and by the shape and dimensions of their toxas, $M$. urizae $\mathrm{n}$. sp. being generally smaller and more gently bent in its middle portion (Table II).

\section{Discușsion}

Hajdu et al. (1995) attempted a preliminary discussion of the likely affinities of the micracanthoxea category of Mycale, arguing that marginally similar occurrences in other poecilosclerid genera (e.g., Neofibularia, Tedania, etc.), are most likely homoplastic characters. We can add also genera outside the order Poecilosclerida (Penares in the Astrophorida, Cliona in the Hadromerida, Desmoxya, Higginsia and Myrmekioderma in the Halichondriida, and Cinachyra in the Spirophorida). Such genera, based on current understandings of higher-taxa relationships within the Demospongiae (e.g., Van Soest, 1991), are most likely far apart from each other in the evolutionary hierarchy. A careful scrutiny of the micromorphology of the micracanthoxeas in each distinct genus, as well as a study of the cells that secrete these spicules, is needed before the status of these occurrences can be established. Such a project goes far beyond the scope of the present article.

Of greater concern to us is the significance of the distribution of the character micracanthoxea in two distinct subgenera of Mycale. This current pattern of occurrences may be explained by several alternative hypotheses. For example, the character could be primitive (hypothesis 1, Fig. 3), evolved in the ancestor of both subgenera, in which case species with micracanthoxeas need not be closely related, if losses had been common. 


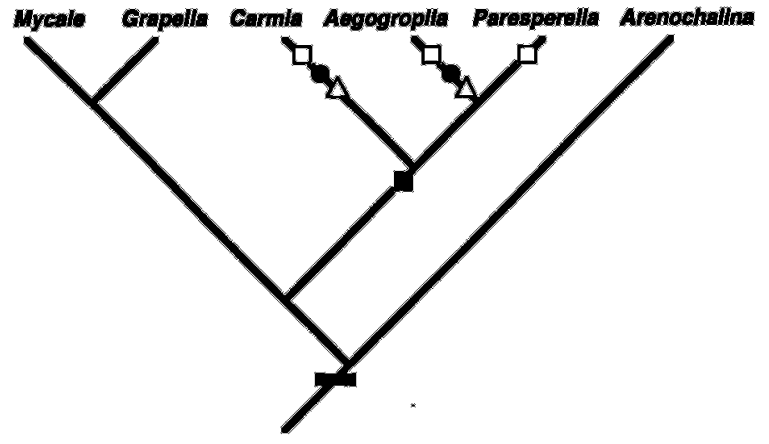

Fig. 3. Hypotheses of character evolution for the micracanthoxeas of the Mycalidae, based on the phylogeny proposed by Hajdu \& Desqueyroux-Faúndez (1994) for the family:

Hypothesis 1 (squares) - single origin plus several independent reversals (losses).

Hypothesis 2 (circles) - single orígin and no known reversals. Species known to have micracanthoxeas would form a monophyletic clade, thus implying the polyphyly of Aegogropila and/or Carmia, since some of the species in one genus would be closer to micracanthoxeas-bearing species in the other genus. Hypothesis 3 (triangles) - two or more independent origins. Hypothesis 4 (rectangle) - bad taxonomy, Single, more inclusive origin, where micracanthoxeas would be postulated to occur in other subgenera too, having been overlooked in former descriptions. Black symbols represent homology. Open symbols represent homoplasy.

Alternatively, micracanthoxeas could be a recent acquisition by a more restricted species-group (hypothesis 2, Fig. 3), which according to the available data would appear to cross taxonomic borders in the current subgeneric classification of Mycale. This is so because some of the species involved possess a reticulated, Aegogropila-type ectosomal skeleton while the others do not, thus conforming to the pattern seen in species currently assigned to Carmia.

Still another possibility may be considered. It is possible that there is a homoplastic occurrence (multiple origins) of micracanthoxeas within $\mathrm{My}$ cale (hypothesis 3, Fig. 3). However, it is disregarded here as highly improbable due to the character's complexity, similarity in distinct species, and unknown functional employment (being thus probably free from adaptive pressures).

The last possibility relates to the unfortunately common disregard in the literature for micromorphology, coupled with quantification (often arbitrary) of disparity (morphospace) in Mycale. The hypothesis we propose here is that micracanthox- eas could be much more widely distributed among species of Mycale (hypothesis 4, Fig. 3), than implied by its known occurrence in only five species pertaining to only two subgenera. Doumenc \& Lévi (1987) pointed out that species of $M y-$ cale may have up to eight categories of microscleres, and Hajdu (1995) mentioned up to four categories of megascleres, four categories of anisochelae, three categories of sigmas, two categories of toxas, two categories of raphides/trichodragmas and one category of micracanthoxeas. Based on such a rich set of morphological features, interspecies comparisons are usually restricted to the numbers of spicule categories present and their dimensions (= length). That this is far from ideal is demonstrated by the detailed spicule descriptions furnished above, which begin to unravel micromorphological features of potential phylogenetic significance (cf. Hajdu \& Van Soest, 1996). In regard to the micracanthoxeas, authors may not only be avoiding the presentation of detailed morphological comparisons, but also may be simply completely overlooking the character. It is beyond the scope of our study to check the dozens of described species for the presence or absence of micracanthoxeas, but from the scarcity of descriptions for which extensive use of SEM has been made, it could be argued that micracanthoxeas might be far more common than presently suggested by the low number of species from which the character has been reported.

Nevertheless, some evidence against the occurrence of micracanthoxeas outside the subgenera from which they are currently known stems from Hajdu \& Desqueyroux-Faúndez's (1994) study, where eight South American species of Mycale (Mycale) were described in detail, without noting a single occurrence of micracanthoxeas, and Hajdu (1995) studied 32 species of the same subgenus (including Grapelia) and found no micracanthoxeas. Material of Mycale (Arenochalina) has already been studied in detail (Hajdu, unpublished results), but no micracanthoxeas were found. It is possible therefore that these microscleres are indeed restricted to the subgenera $\mathrm{Ae}$ gogropila and Carmia. Among the currently widely used Mycäle subgeneric assemblages, only Par- 
esperella remains to be thoroughly investigated.

Given the above considerations it is clear that the use of the character micracanthoxeas in species-level phylogenetic analyses is premature in the absence of a thorough revision of more than 100 species assigned to Aegogropila, Carmia, and Paresperella. At the subgeneric level though, chances are that the character may be an additional synapomorphy for the assemblage comprising the three subgenera mentioned above (cf. Hajdu \& Desqueyroux-Faúndez, 1994), especially if the concept of underlying synapomorphy (e.g., Saether, 1983) is employed.

\section{Acknowledgements}

JLC wishes to thank the Ministry of Fisheries and Marine Resources of the Republic of Namibia for the facilities provided, as well as to Miss B. Curry and K. Grobler from the Fisheries Centre of the Republic of Namibia for their help in the scientific expedition where the species $M$. urizae was collected. Part of this work was made possible through a post-doc fellowship for research and development given by the Dirección General de Investigación Científica y Técnica del Mínisterio de Educación y Ciencia de España. EH is thankful to A. Ribeiro and M.V.Cruz (Laboratório de Microscopia Eletrônica, Departamento de Biologia, Instituto de Biociências, Universidade de São Paulo, São Paulo, SP, Brazil) for the provision of SEM facilities, and E. Mattos (Departamento de Zoologia, Instituto de Biociências, Universidade de São Paulo, SP, Brazil) for technical support during SEM operation. G. Muricy (Departamento de Zoologia, Instituto de Biologia, Universidade Federal do Rio de Janeiro, RJ, Brazil) is thanked for help with the collection of specimens in São Sebastião. R.W.M. van Soest and D. Platvoet (Institute for Systematics and Population Biology, University of Amsterdam, The Netherlands) are thanked, respectively, for the provision of SEM facilities, and technical support during SEM operation. This study was supported in part by FAPESP and FUJB/UFRJ.

\section{References}

Bowerbank, J.S., 1866. A monograph of the British Spongiadae, II: i-xviii, 1-388 (Ray Society, London).

Buizer, D.A.G. \& R.W.M. van Soest, 1977. Mycale micracanthoxea nov, spec. (Porifera, Poecilosclerida) from The Netherlands. Neth. J. Sea Res., 11 (3/4): 297-304.

Carballo, J.L. \& J.C. García-Gómez, 1994. The Northeastern Atlantic species Mycale micracanthoxea Buizer \& Vart Soest, 1977 (Porifera, Poecilosclerida) in the Strait of Gibraltar (southern Spain). Beaufortia, 44(2): 11-16.

Doumenc, D. \& C. Lévi, 1987. Anisochelae analysis and taxonomy of the genus Mycale Gray (Demospongiae). In: J.
Vacelet \& N. Boury-Esnault (eds.), Taxonomy of Porifera from the northeast Atlantic and Mediterranean Sea: 73-92 (Springer Verlag, Berlin).

Gray, J.E., 1867. Notes on the arrangement of sponges, with the description of some new genera. Proc. zool. Soc. Lond., 1867: 492-558.

Hajdu, E, 1994. A phylogenetic interpretation of hamacanthids (Demospongiae, Porifera) with a redescription of Hamacantha popana (De Laubenfels, 1935). J. Zool, 232; 61-77.

Hajdu, E., 1995. Macroevolutionary patterns within the demosponge order Poecilosclerida. Phylogeny of the marine cosmopolitan genus Mycale, and an integrated approach to biogeography of the seas: 1-173 (Ph.D. thesis, Univ. of Amsterdam).

Hajou, E. \& R. Desqueyroux-Faúndez, 1994. A synopsis of South American Mycale (Mycale) (Poecilosclerida, Demospongiae), with description of three new species and a cladistic analysis of Mycalidae. Revue suisse Zool., 101 (3): 563-600.

Hajdu, E. \& R.W.M. van Soest, 1996. Choosing among poriferan morphological characters within the cladistic paradigm. Bull, Inst. roy. Sci. nat. Belg., Biol., 66: 81-88.

Hajdu, E., R.W.M. van Soest \& J.N.A Hooper, 1994. Proposal for a phylogenetic subordinal classification of poecilosclerid sponges. In: R.W.M. van Soest, Th. M.G. van Kempen \& J.C. Braekman (eds.), Sponges in time and space: 123-139 (Balkema, Rotterdam).

Hajudu, E., S. Zea, M. Kielman \& S. Peixinhho, 1995. Mycale escarlatei n. sp. and Mycale unguifera n. sp. (Demospongiae) from the tropical-western * Atlantic. Beaufortia, 45(1): 1-16.

Lundbeck, W, 1905. Porifera (Part 2). Desmacidonidae (pars). Danish Ingolf Exped., 6: 1-124.

Reiswig, H.M. \& H. Kaiser, 1989. Description of Mycale bamfieldense n. sp. (Porifera, Demospongiae, Poecilosclerida) from Vancouver Island, British Columbia. Can. J. Zool, 67: 674-677.

Rützler, K, 1978. Sponges in coral reefs. In: D.R. Stoddart \& R.E. Johannes (eds.), Coral reefs: research methods. Monographs on oceanographic methodology, 5: 299-313 (Unesco, Paris).

Saether, O.A., 1983. The canalized evolutionary potential: inconsistencies in phylogenetic reasoning. Syst. Zool, 32: 343-359.

Soest, R.W.M. van, 1991. Demosponge higher taxa classification re-examined. In: J. Reitner \& H. Keupp (eds.), Fossil and recent sponges: 54-71 (Springer-Verlag, Berlin/ Heidelberg).

Thomas, P.A., 1968. Studies on Indian sponges - III. Two species of silicious sponges of the family Ophlitaspongìdae De Laubenfels (Demospongiae, Poecilosclerida). J. mar, biol. Ass. India, 10 (2): 255-259.

Topsent, E., 1928. Spongiaires de 1'Atlantique et de la Mediterranée provenant des croisières du Prince Albert $1^{\text {er }}$ de Monaco. Résult. Camp. scient. Prince Albert I, 74: 1-376.

Received: 15 May 1997 